\title{
Wide local excision and sentinel lymph node biopsy in early breast cancer in Duhok city
}

\author{
Sardar Hassan Arif* , Ayad Ahmad Mohammed* \\ * Department of Surgery, College of Medicine, University of Duhok, Duhok, Kurdistan Region, Iraq. \\ Correspondence: sardar.arif@uod.ac
}

(Ann Coll Med Mosul 2020; 42 (1):19-26).

Received: $19^{\text {th }}$ April 2020; Accepted: $22^{\text {th }}$ May 2020.

\begin{abstract}
Objectives: Breast conservation surgery widely in form of wide local excision and sentinel lymph node biopsy in the management of patients presenting with early breast cancer.

The aim of this study is to analyze the effectiveness of the of the breast conservation surgery and sentinel lymph node biopsy using the methylene blue dye.

Methods: this retrospective cross sectional study conducted at Nov.2014 - Dec.2019 Ninety-six females Patients with stage I and II breast cancer were included in this, patients with stage III and IV, clinically suspicious axillary lymph nodes, and male patients were excluded from this study.

Injection of methylene blue dye done around the breast mass. Resection of the breast tumor done until negative margins achieved, then dissection of the axilla was done and the stained lymph node or nodes were excised and were sent for frozen section examination, when the result was negative no further axillary dissection were done, but when result was positive we did axillary lymph node dissection.

Results: The current study showed a sensitivity of $93 \%$, specificity of $82 \%$, positive predictive value of $85 \%$, negative predictive value of $92 \%$, and the accuracy of the procedure was $88 \%$.

The most frequent complication was seroma formation and wound infection in $12.5 \%$ and $7.3 \%$ respectively, some dye related complications were reported including tattooing of the skin in $10.4 \%$ of patients, blue urine in $3.1 \%$ of patients and mild allergic reactions in $2 \%$ of patients.

Conclusions: The technique of wide local excision and SLN biopsy using the methylene blue dye is safe and effective technique for breast conservation surgery especially in the regions were no facilities are available for the radiolabeled colloid. Breast conservation surgery has comparable outcome to mastectomy.
\end{abstract}

Keywords: Axillary lymph node surgery, Breast cancer, Frozen section examination, Methylene blue dye, Sentinel lymph node.

$$
\begin{aligned}
& \text { استئصال الثدي الجزئي وخزعة العقدة الليمفاوية الحارسية لسرطان الثدي المبكر } \\
& \text { في مدينة دهو }
\end{aligned}
$$

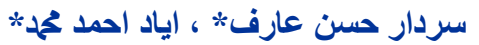

$$
\begin{aligned}
& \text { *ققم الجراحة , كلية الطب , جامعة دهوك , العراق }
\end{aligned}
$$

الأهداف: تستخدم جراحة الحفاظ على الثدي على نطاق واسع بواسطة الاستئصال الموضعي الواسع وخزعة العقدة الليمفاوية

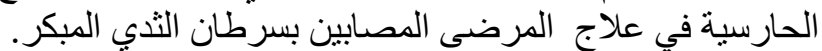

الهدف من هذه الدراسة هو تحليل فعالية جراحة الحفاظ على الثذي وخزعة العقدة الليمفاوية الخافرة باستخدام صبغة الميثيلين الزرقاء.

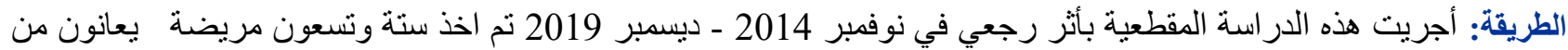

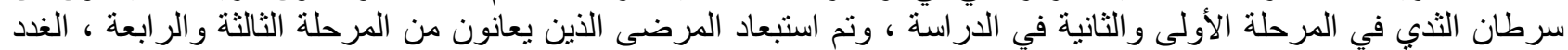

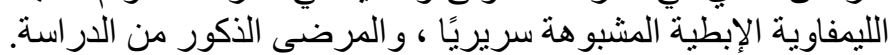

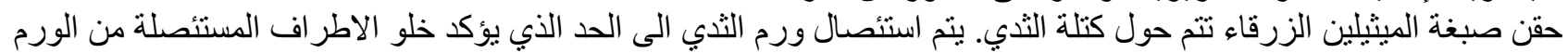

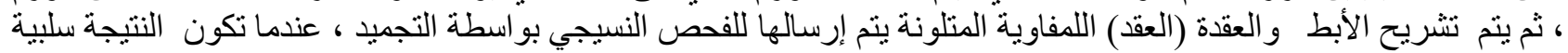
لا يتم إجراء تشريحي اضافي للابط ، ولكن عندما تكون النتيجة إيجابية فيتم اكمال التشريح لاستئصال العقد الليمفاوية. 
النتائج: أظهرت الدر اسة الحالية نسبة حساسية العملية 93 ٪ ، نسية خصوصية العملية 82 ٪ ، القيمة التنبؤية الإيجابية 85 ٪ ؛

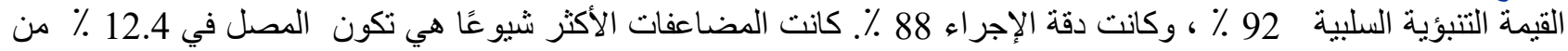

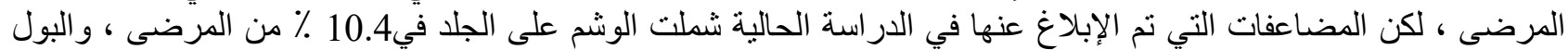

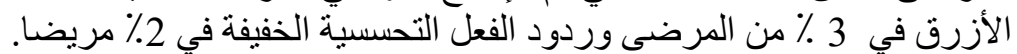

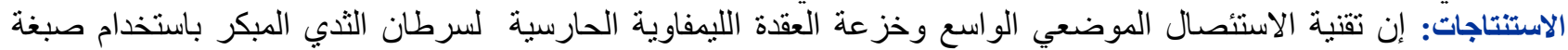

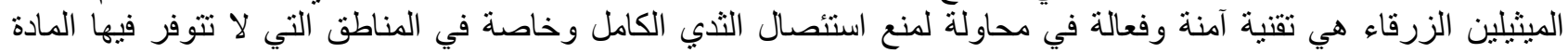
الغروية المشعة.

الكلمات المفتاحية: تثريح العقدة الليمفاوية الإبطية ، سرطان الثذي ، الفحص النسيجي المتجمد ، صبغة الميثيلين الزرقاء ، العقدة الليمفاوية الحارسة.

\section{INTRODUCTION}

reast cancer is the commonest type of cancer that affects women during their lifetime worldwide, surgery is the main option of treatment in most patients. Breast conservation surgery has a comparable outcome in long term survival with mastectomy, but it has the advantages of better cosmetic results, lower psychological disturbance with improved selfesteem and sexuality. 1-4 $^{-4}$

The most important goal during surgery is complete surgical resection of the tumor with a negative rim of tissue. The definition of negative margin is still controversial. In the past, the margins were considered negative, only if they were $>1 \mathrm{~cm}, 5,6$ however a meta-analyses study showed that equivalent percentages of local tumor recurrence are achieved with margins as close as 1-2 mm. ${ }^{7,8}$

A meta-analysis study showed that wider surgical margins don't improve the disease local recurrence. ${ }^{9}$ In situ lobular cancer or atypical duct hyperplasia, when present at the surgical margins, don't increase the local recurrence of the disease. ${ }^{10,11}$

If the tumor is deeply sited in the breast and there is no skin invasion, excessive skin excision is not recommended. The excised specimen should be marked anatomically before sending it to the laboratory for histopathological examination. ${ }^{12}$

There are many contraindications to this type of surgery such as inflammatory breast cancer, multifocal breast cancer, extensive skin invasion, and thoracic wall invasion. ${ }^{13}$

The technique of axillary sentinel lymph node biopsy (SLNB) include detection and removal of the first lymph node that drain the tumor harboring region. ${ }^{14}$ SLNB may prevent further axillary LN dissection, thus preventing its complications such as lymphedema, nerves injury, seroma collection, and chronic axillary pain. ${ }^{14,15}$

The feasibility of wide local excision and sentinel lymph node assessment in the management of patients presenting with early breast cancer was assessed in the present clinical study.

\section{Research Registration}

The approval of the study is gained from the Ethical committee of Duhok Directorate of General Health, The Scientific Research Department, contact E-mail: scientific.research@duhokhealth.org.

According to the World Medical Association's Declaration of Helsinki at 2013, the research is also registered at research registry at the $23^{\text {rd }}$ of October, 2019, the unique identifying number (UIN): research registry 5188 .

\section{PATIENTS AND METHODS}

\section{Design of The Study}

This retrospective cross sectional study conducted at Nov.2014 - Dec.2019 , the patients visited the private clinic of the authors for the skeptical breast malignancy were consecutively assessed through triple methods, including clinical examination, ultrasound and/or mammography, and tissue sampling with tru-cut biopsy for eligibility criteria. A total number of 96 females with clinical stage I and stage II cancer of the breast were included in this study. The subjects were recruited from a single center in Duhok-Iraq.

\section{Inclusion and Exclusion Criteria}

Female patients who diagnosed as stage I and stage II breast cancer were included in the study. Patients having advanced disease, recurrent disease, patients with clinically suspicious involved axillary LN involvement, or patients in whom the operation converted to mastectomy were excluded from this study. 


\section{Clinical Procedures}

All the clinical procedures were conducted under general anesthesia. The mass localized with ultrasound or mammography, and $10 \mathrm{ml}$ of methylene blue dye injected in 4 sites around the mass in the subdermal region. We waited 15 minutes for the dye to be transferred with the lymphatics to the axillary lymph nodes. The mass excised with a rim of normal looking tissue and was sent for histopathological unit for examination of the tumor and the surgical edges by the frozen section technique. The edges of the resected margins were marked for the pathologist by suture materials or colored to guide the surgeon and the pathologist during surgery if any further excision needed at the specified edge, as shown in figure 1.

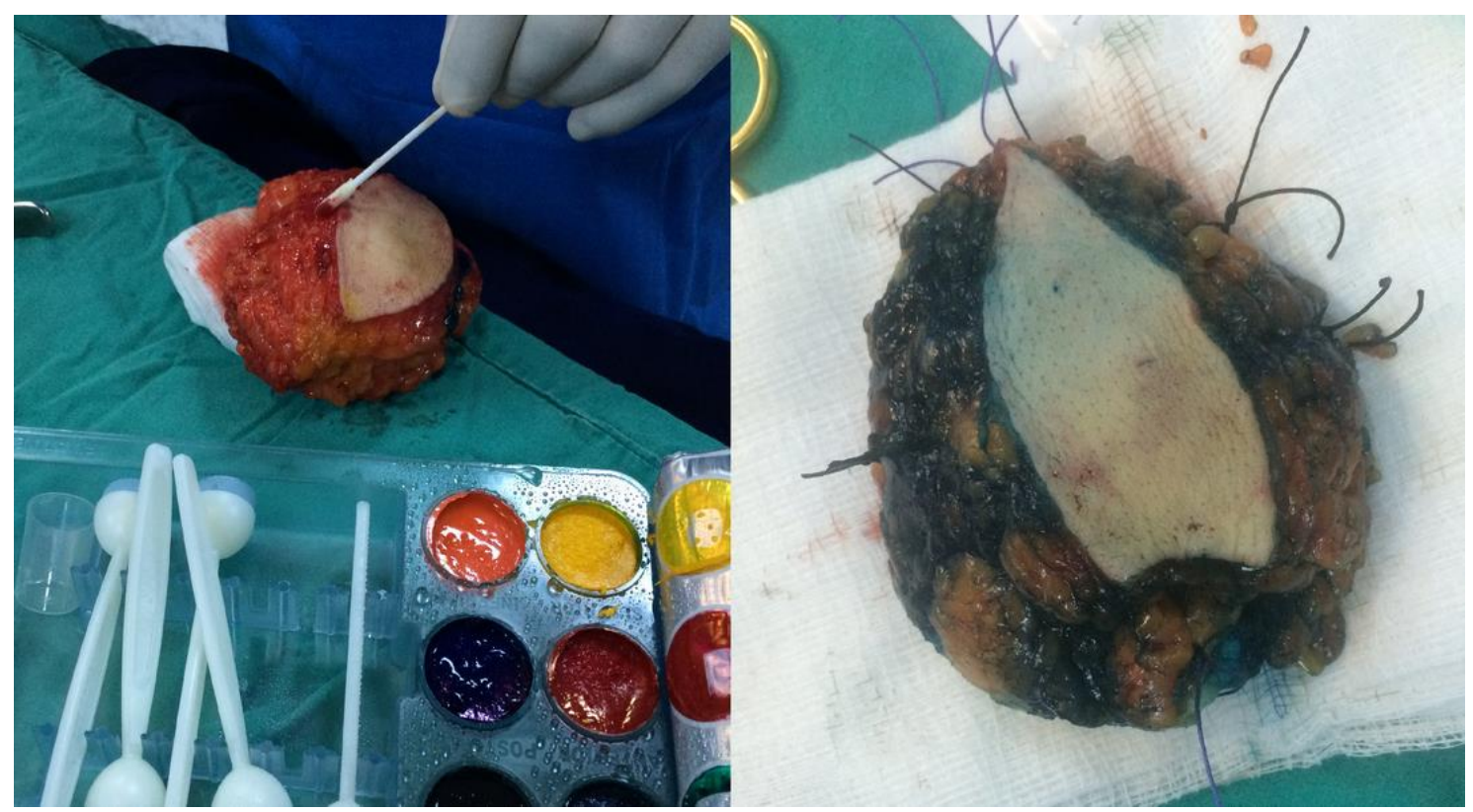

Figure 1: A picture illustrating marking of the edges of the sample before sending it to the pathologist using different types of suture materials or coloring the edges.

Dissection of the axilla then started searching for any staining lymph node/nodes which were removed and sent for histopathological study by frozen section machine, sometimes the lymphatic channels are stained and we followed them which may guide to the LN. Positive involvement of the SLN with malignancy mandated axillary LN dissection. No patient underwent preoperative neoadjuvant chemo or radiotherapy as shown in figure $2 \& 3$.

Figure 2: An intraoperative picture showing the blue dye passing in one of the lymphatic vessels.

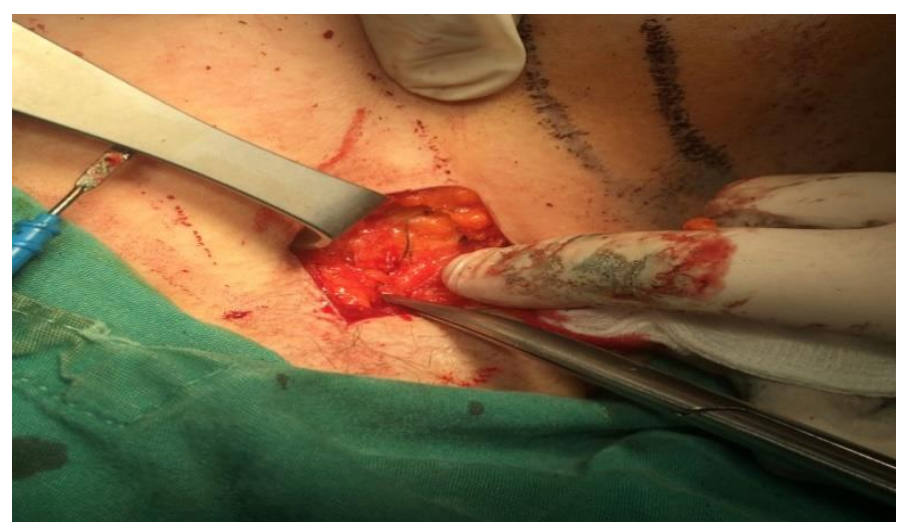




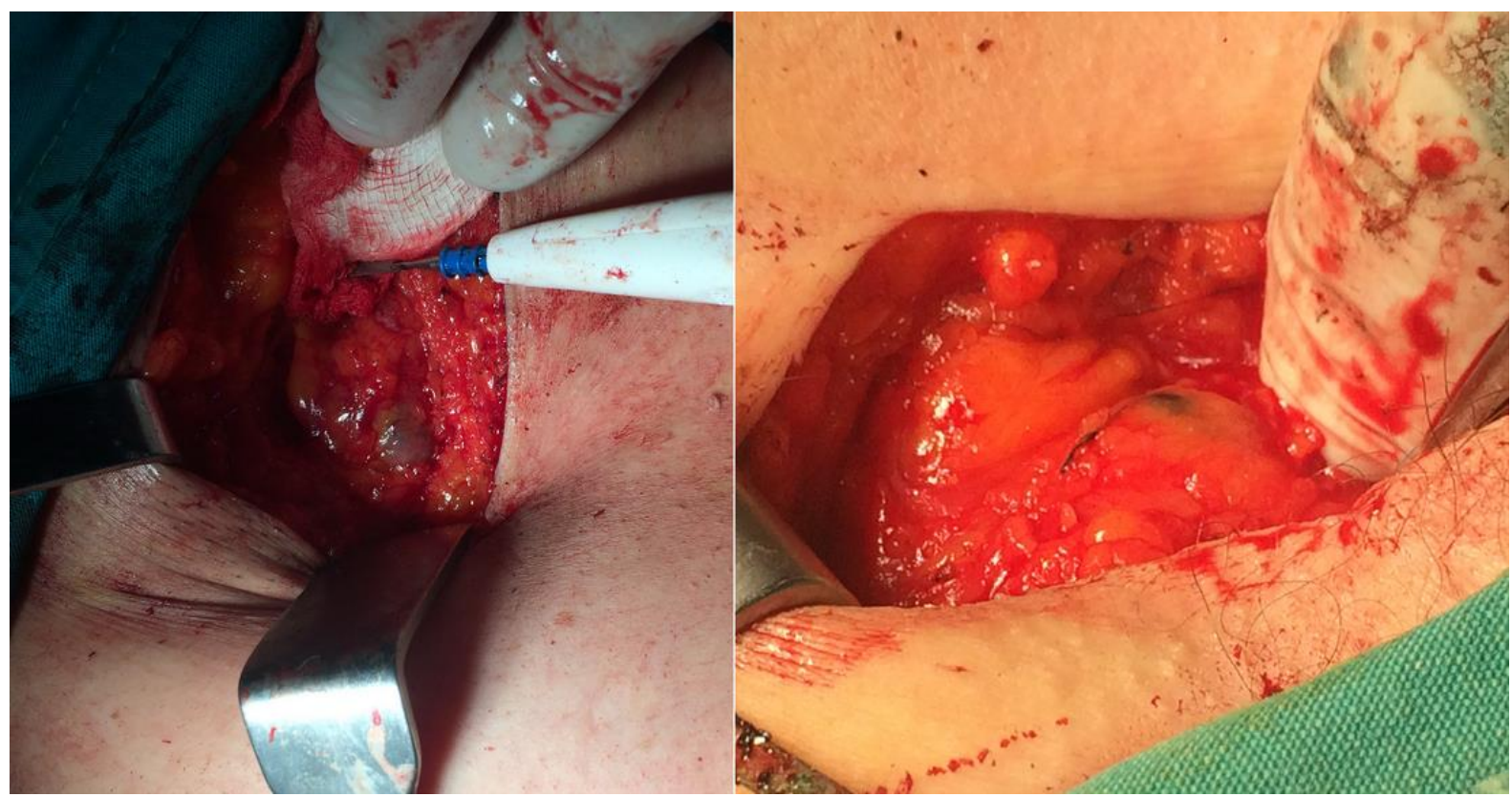

Figure3: Axillary LN that took the blue dye, it may be a single one or multiple nodes.

\section{Diagnostic and Measurement Criteria}

The diagnosis of cancer of the breast is usually done on the basis of triple assessment; i.e. any suspicious lesion clinically or radiologically is assessed by the histopathological examination which gives the definite diagnosis and supported by immunohistochemical examination in order to determine the mode of therapy. ${ }^{16}$

The surgical outcome in patients who underwent breast conservation surgery has been shown by the studies to be superior the patients with the more radical surgery in terms of body image and surgical complications. ${ }^{17}$

\section{Statistical Analysis}

Descriptive values in the study were displayed in frequency and percentage for categorical data, and mean and standard deviation for continuous data.

Sensitivity is defined as the ability of a test to accurately diagnose an individual as having the disease $(T P / T P+F N)$, the specificity is defined as the ability of a test to accurately exclude the presence of the disease (TN/TN+FP), the positive predictive value (PPV) is the percentage of patients with a positive test who actually have the disease (TP/TP+FP), and the negative predictive value (NPP) is the percentage of patients with a negative test who actually do not have the disease ( TN/FN+TN). ${ }^{18}$

Statistical calculations were performed using the Statistical Package for Social Sciences (SPSS 25:00 IBM: USA).

\section{RESULTS}

The mean age of the patients who were included in this study was 45.55 (SD: 11.60 years) and the size of their tumor was 27.25 (SD: $12.72 \mathrm{~cm}$ ). The tumor of the most of the patients was in left side (61.5\%); see Table 1.

Table 1: Baseline information of patients.

\begin{tabular}{|l|l|l|}
\hline $\begin{array}{l}\text { General and clinical } \\
\text { information }(\mathrm{n}=96)\end{array}$ & Mean & $\begin{array}{l}\text { Standard } \\
\text { deviation }\end{array}$ \\
\hline Age in years & 45.55 & 11.60 \\
\hline Tumor size in mm & 27.25 & 12.72 \\
\hline Site of the tumor; $\mathrm{F}, \%$ & & \\
Left breast & 59 & 61.5 \\
Right breast & 37 & 38.5 \\
\hline
\end{tabular}

The mean number of the SLNB and the axillary LN that were involved by the tumor was single LN, the mean number of axillary LNs that were removed after completion of the axillary LN dissection is 8.5, the SLN was positive in 54 cases (65.3\%). The majority of the surgical margins in our samples were negative $75 \%$. In 84 patients $(87.5 \%)$ the tumor type was invasive ductal carcinoma. The most frequent complication was seroma formation which represent both the site of breast excision and the axilla, Infection reported in 7 patients $(7.3 \%)$ which was superficial infection and include both the axilla and the breast site, table 2 . 
Table 2: Outcomes of wide local incision.

\begin{tabular}{|c|c|c|}
\hline $\begin{array}{l}\text { Clinical information } \\
(\mathrm{n}=96)\end{array}$ & Frequency & Percentage \\
\hline $\begin{array}{l}\text { Number of the SLN } \\
\text { removed; M, SD }\end{array}$ & 1.00 & 2.00 \\
\hline $\begin{array}{l}\text { Number of the } \\
\text { axillary LN involved } \\
\text { by the tumor; M, SD }\end{array}$ & 1.00 & 4.00 \\
\hline $\begin{array}{l}\text { Total number of the } \\
\text { LN removed; M (SD) }\end{array}$ & 8.50 & 10.75 \\
\hline $\begin{array}{l}\text { SLN Status; } n(\%) \\
\text { Positive } \\
\text { Negative }\end{array}$ & $\begin{array}{l}54 \\
42\end{array}$ & $\begin{array}{l}56.3 \\
43.8\end{array}$ \\
\hline $\begin{array}{l}\text { Status of the } \\
\text { surgical margins } \\
\text { Negative margins } \\
\text { Positive margins } \\
\text { Near margins }\end{array}$ & $\begin{array}{l}72 \\
12 \\
12\end{array}$ & $\begin{array}{l}75.0 \\
12.5 \\
12.5\end{array}$ \\
\hline $\begin{array}{l}\text { Histopathological } \\
\text { diagnosis } \\
\text { IDC } \\
\text { ILC } \\
\text { MC } \\
\text { Borderline phyllodes } \\
\text { tumour } \\
\text { FA+IDC }\end{array}$ & $\begin{array}{l}84 \\
4 \\
6 \\
1 \\
1\end{array}$ & $\begin{array}{l}87.5 \\
4.2 \\
6.3 \\
1.0 \\
1.0\end{array}$ \\
\hline $\begin{array}{l}\text { Postoperative } \\
\text { complications } \\
\text { Seroma formation } \\
\text { Tattooing } \\
\text { Infection } \\
\text { Blue urine } \\
\text { Mild allergic reaction } \\
\text { Wound dehiscence }\end{array}$ & $\begin{array}{l}12 \\
10 \\
7 \\
3 \\
2 \\
1\end{array}$ & $\begin{array}{l}12.5 \\
10.4 \\
7.3 \\
3.1 \\
2 \\
1\end{array}$ \\
\hline \multicolumn{3}{|c|}{$\begin{array}{l}\text { IDC: Invasive ductal carcinoma, ILC: Invasive } \\
\text { lobular carcinoma, MC: Medullary carcinoma, FA } \\
\text { Fibroadenoma. }\end{array}$} \\
\hline
\end{tabular}

The sensitivity of the surgeries in this study was $93 \%$, and the specificity was $82 \%$, table 3 .

Table 3: Predicting indicators of surgery outcome

\begin{tabular}{|l|l|l|l|l|l|l|l|l|}
\hline \multicolumn{7}{|c|}{ Predicting Indicators } \\
\hline $\mathrm{T}$ & $\mathrm{F}$ & $\mathrm{T}$ & $\mathrm{F}$ & $\begin{array}{l}\text { Sensit } \\
\text { ivity }\end{array}$ & $\begin{array}{l}\text { Specif } \\
\text { icity }\end{array}$ & $\begin{array}{l}\mathrm{P} \\
\mathrm{P}\end{array}$ & $\begin{array}{l}\mathrm{N} \\
\mathrm{N}\end{array}$ & $\begin{array}{l}\text { Accur } \\
\text { acy } \\
\mathrm{V}\end{array}$ \\
\hline 4 & 8 & 3 & 3 & $93 \%$ & $82 \%$ & $\begin{array}{l}85 \\
\%\end{array}$ & $\begin{array}{l}92 \\
\%\end{array}$ & $88 \%$ \\
6 & & 9 & & & & \\
\hline
\end{tabular}

TP: True Positive; FP: False Positive; TN: True Negative; FN: False Negative; PPV: Positive Predicative Value; and NPV: Negative Predictive value

\section{DISCUSSION}

Breast conservation surgery become the standard management option for patients with early breast cancer worldwide, one of the major advantages of this technique is lower rate of complications which result from axillary lymph nodes dissection. ${ }^{15}$

The left breast was involved in the majority of our patients $(n=59,61.5 \%)$, however this may not reflect the true incidence regarding the site of involvement because the current study included only stage one and stage two of breast cancer, this is slightly lower than the studies that used the same criteria for patient selection. ${ }^{19}$

The mean tumor size in patients who were included in this study was $27.25 \mathrm{~mm}$, smaller size tumors usually don't present to the breast consultation clinic because they may be difficult to diagnose particularly in the context of large size breast, and they may only be discovered in the areas of routine screening. Larger tumors may be associated with clinically suspicious axillary LN and most cases had been excluded.

The definition of adequate surgical margins is still controversial, most breast surgeons are convinced that $2 \mathrm{~mm}$ negative margins and more can be considered adequate, others insist that more than $5 \mathrm{~mm}$ margins are considered adequate, however in most studies, authors have shown that there is no any significant difference in terms of local disease recurrence between the two involved groups. $^{20}$

In a review of a large number of literature concerning adequate surgical margins, all authors concluded that it is "absolutely unacceptable to have tumor cells at the cut edge of the excised specimen, regardless of the type of post-surgical adjuvant therapy". ${ }^{21}$ Another study which included both surgeons and pathologists, both were asked about the adequate surgical margin that can be considered adequate, most of the pathologists agreed that a rim of $1-2 \mathrm{~mm}$ normal margins can be considered safe, while most of the surgeons considered more than $2 \mathrm{~mm}$ to be regarded as adequate. $^{22}$

In this study, had been considered $5 \mathrm{~mm}$ and more to be considered as negative \& less than this was considered to be near margin. In 72 patients $(75 \%)$ the surgical margins were negative and no more excision was performed in the breast, in $12.5 \%$ of patients with near margins we did further excision of that margin, in patients with positive margins after excision also we did re-excision of the involved margin until negative margins were achieved, in $4 \%$ of patients was unable to achieve negative surgical margins and the operation converted to modified radical mastectomy, those patients were excluded from 
the current study. Some other authors also considered negative margins to be more than 2 $\mathrm{mm}{ }^{23}$

The spread of malignant cells through the lymphatic channels is thought to be sequential; i.e. cancer will spread to level I lymph nodes then pass to level II and so on, in some rare occasions there may be skip metastasis which mean it may not follow this sequence of spread, this had been reported to occur in around $2-4 \%$ of the cases. ${ }^{24,25}$ The detection of the SLN may be performed adopting a variety of techniques depending on the practice of the surgeons. Most authors use a blue dye (isosulphane blue or methylene blue) in combination with radio-labelled colloid substance, a gamma probe detector is used to localize the SLN. This is called the combined technique and is associated with higher detection rates; however, the blue dye alone is used by some surgeons. ${ }^{26,15}$ In this study the technique were used is the methylene blue dye alone for the detection of SLN because of its fewer complications compared to isosulphane blue. Currently there are no clear national or international guidelines for the use of the blue dye regarding its volume and concentration as there is no statistically significant difference in terms of detection rates regarding the volume and concentration or the size of the tumor. Many complications of the blue dye had been reported and they may occur in $0.6-2.5 \%$ of the patients, the most serious one is the hypersensitivity and anaphylaxis which may be fatal in some cases, other complications include skin or fat necrosis, local fibrosis, blue urine or tattooing of the skin which is usually transient. ${ }^{27}$

In the present study $10.4 \%$ of patients developed skin tattooing and $3.1 \%$ of patients developed blue urine, urine discoloration resolved after 24 hours in all patients, all patients with skin tattooing resolved but the period of resolution was poorly documented. Fortunately, no patients developed severe allergic reaction but $2 \%$ of patients developed mild allergic reaction in the form of skin itching and urticarial reaction which resolved with single dose of intravenous hydrocortisone $100 \mathrm{mg}$.

In most patients a separate axillary incision was made to search for the SLN, however when the mass was near the axilla (upper outer quadrant of the breast), we just extent the same incision of the breast to the axilla. The lymphatic vessels may be seen stained with the dye; in such case they may guide the surgeon to the site of the SLN.

The rate of detection of the SLN in the used technique was $97 \%$, and in about $25 \%$ of patients more than one LN stained with the dye, all considered to be the SLNs and were excised and sent for the frozen section examination.
In this study the SLN truly represented the axillary status in $86 \%$ of patients. Studies showed an approximate rate of SLN detection rate using the same dye $(93 \%)$ but higher rate of SLN representation of the axillary status $(97 \%){ }^{28}$

The accuracy of the technique in this study was $(88 \%)$ which is comparable with most of the studies worldwide, studies also showed higher accuracy rates with methylene blue (92.7\%) compared to isosulphane blue $\left(88.5 \%\right.$.). ${ }^{29}$ In recent practice several techniques are under investigations like the use of the super paramagnetic nanoparticles and hand-held magnetometer, these techniques show higher detection rates which may reach up to $99 \%$ and the use of fluorescent technique like the use of indocyanine green and fluorescent cameras which have a very high detection rate that may reach $100 \%$. $^{30-34}$

During the learning process of SLNB axillary LN dissection must be performed after the detection of the SLN, both results should be comparable, when the detection rate reach more than $90 \%$ with less than $5 \%$ false negative rates this may indicate that SLNB can be done alone without axillary LN dissection, most authors accept that 30 cases are enough for this learning process. ${ }^{35}$

\section{CONCLUSIONS}

The technique of wide local excision and SLN biopsy using the methylene blue dye is safe and effective technique for breast conservation surgery especially in the regions were no facilities are available for the radiolabeled colloid. At the present time there are no clear international guidelines regarding the volume and the concentration of the dye. The combined technique using the radiolabeled colloid and the dye have better results than the blue dye alone but the techniques need to be available.

Conflict of interest: No conflict of interest is present to be declared.

Source of funding: The author is the source of the funding. 


\section{REFERENCES:}

1 Abe R , Asaishi K, Enomoto K, Hattori T, lino Y, et al. Effects of radiotherapy and surgery in early breast cancer-an overview of the randomized trials. N Engl J Med. 1995;333(22):1444-56.

2 Al-Ghazal S, Fallowfield L, Blamey R. Comparison of psychological aspects and patient satisfaction following breast conserving surgery, simple mastectomy and breast reconstruction. Eur J Cancer. 2000;36(15):1938-43.

3 Mohammed A. Quantitative assessment of Ki67 expression in correlation with various breast cancer characteristics and survival rate; cross sectional study. Ann Med Surg. 2019;48:129-34.

4 Mohammed A . Predictive factors affecting axillary lymph node involvement in patients with breast cancer in Duhok: Cross-sectional study. Ann Med Surg. 2019;44:87-90.

5 Fisher B, Anderson S, Bryant J, Margolese R, Deutsch M, Fisher E, et al. Twenty-year followup of a randomized trial comparing total mastectomy, lumpectomy, and lumpectomy plus irradiation for the treatment of invasive breast cancer. N Engl J Med. 2002;347(16):1233-41.

6 Veronesi U, Cascinelli N, Mariani L, Greco M, Saccozzi R, Luini A, et al. Twenty-year follow-up of a randomized study comparing breastconserving surgery with radical mastectomy for early breast cancer. $\mathrm{N}$ Engl $\mathrm{J}$ Med. 2002;347(16):1227-32.

7 Houssami N, Macaskill P, Marinovich M, Dixon J, Irwig L, Brennan M, et al. Meta-analysis of the impact of surgical margins on local recurrence in women with early-stage invasive breast cancer treated with breast-conserving therapy. Eur $\mathrm{J}$ Cancer. 2010;46(18):3219-32.

8 Houssami N, Macaskill P, Marinovich ML, Morrow M. The Association of Surgical Margins and Local Recurrence in Women with Early-Stage Invasive Breast Cancer Treated with Breast-Conserving Therapy: a Meta-analysis. Ann Surg Oncol. 2014 Mar;21(3):717-30

9 Singletary S E. Surgical margins in patients with early-stage breast cancer treated with breast conservation therapy. Am J Surg. 2002;184(5):383-93.

10 Fowble B, Hanlon AL, Patchefsky A, Freedman G, Hoffman JP, Sigurdson ER, et al. The presence of proliferative breast disease with atypia does not significantly influence outcome in early-stage invasive breast cancer treated with conservative surgery and radiation. Int $\mathrm{J}$ Radiat Oncol Biol Phys. 1998;42(1):105-15.

11 Abner A, Connolly J, Recht A, Bornstein B, Nixon A, Hetelekidis $S$, et al. The relation between the presence and extent of lobular carcinoma in situ and the risk of local recurrence for patients with infiltrating carcinoma of the breast treated with conservative surgery and radiation therapy. Cancer. 2000;88(5):1072-7.

$12 \mathrm{NIH}$ consensus conference. Treatment of earlystage breast cancer. Jama. 1991;265(3):391-5.

13 White J, Achuthan R, Turton P, Lansdown M. Breast Conservation Surgery: State of the Art. Int J Breast Cancer. 2011;2011.

14 Mansel R, Fallowfield L, Kissin M, Goyal A, Newcombe $\mathrm{R}$, Dixon $\mathrm{J}$, et al. Randomized multicenter trial of sentinel node biopsy versus standard axillary treatment in operable breast cancer: the ALMANAC Trial. J Natl Cancer Inst. 2006;98(9):599-609.

15 Kumar A, Puri R , Gadgil P , Jatoi I . Sentinel lymph node biopsy in primary breast cancer: window to management of the axilla. World J Surg. 2012;36(7):1453-9.

16 Clarke D, Sudhakaran N, Gateley C . Replace fine needle aspiration cytology with automated core biopsy in the triple assessment of breast cancer. Ann R Coll Surg Engl. 2001;83(2):110.

17 Kosir M , Rymal C, Koppolu P , Hryniuk L , Darga L , Du W, et al. Surgical outcomes after breast cancer surgery: measuring acute lymphedema. J Surg Res. 2001;95(2):147-51.

18 Parikh R, Mathai A, Parikh S , Sekhar G , Thomas $R$. Understanding and using sensitivity, specificity and predictive values. Indian $\mathrm{J}$ Ophthalmol. 2008:56(1):45.

19 Özdemir A, Mayir B , Demirbakan K, Oygür N . Efficacy of methylene blue in sentinel lymph node biopsy for early breast cancer. J Breast Health. 2014;10(2):88.

20 Giacalone P, Roger P , Dubon O , Gareh N , Rihaoui S, Taourel $\mathrm{P}$, et al. Comparative study of the accuracy of breast resection in oncoplastic surgery and quadrantectomy in breast cancer. Ann Surg Oncol. 2007;14(2):605-14.

21 Singletary $S$. Surgical margins in patients with early-stage breast cancer treated with breast conservation therapy. Am J Surg. 2002;184(5):383-93. 
22 Young OE, Valassiadou K, Dixon M. A review of current practices in breast conservation surgery in the UK. Ann R Coll Surg Engl. 2007;89(2):118-23.

23 Hamdi M , Sinove Y, DePypere H, Broucke VD, Vakaef L, Cocquyt V , et al. The role of oncoplastic surgery in breast cancer. Acta Chir Belg. 2008;108(6):666-72.

24 Veronesi U, Rilke F, Luini A, Sacchini V, Galimberti V , Campa T, et al. Distribution of axillary node metastases by level of invasion. An analysis of 539 cases. Cancer. 1987;59(4):6827.

25 Mahdi A, Ibrahim H, Mohammed A . Ki67 Expression as an Indicator of Invasiveness in Patients with Breast Cancer. Med J Babylon. 2018;15(4):271-5.

26 Morrow M , Rademaker A, Bethke $\mathrm{K}$, Talamonti M , Dawes L , Clauson J , et al. Learning sentinel node biopsy: results of a prospective randomized trial of two techniques. Surgery. 1999;126(4):714-22.

27 Altıntoprak F, İğci A, Asoğlu O, Gök K, Müslümanoğlu $M$, Özmen $V$, et al. Allergic reaction due to subareolar isosulphane blue dye injection for sentinel lymph node biopsy: Case Report. J Breast Health. 2006;2:34-6.

28 Simmons R, Thevarajah S, Brennan M , Christos $\mathrm{P}$, Osborne $\mathrm{M}$. Methylene blue dye as an alternative to isosulfan blue dye for sentinel lymph node localization. Ann Surg Oncol.. 2003;10(3):242-7.

29 Blessing W, Stolier A, Teng S, Bolton J , Fuhrman $G$. A comparison of methylene blue and lymphazurin in breast cancer sentinel node mapping. Am J Surg. 2002;184(4):341-5.

30 Ahmed M, Purushotham A, Douek M. Novel techniques for sentinel lymph node biopsy in breast cancer: a systematic review. Lancet Oncol. 2014;15(8):e351-e62.

31 Guo W , Zhang L , Ji J , Gao W , Liu J , Tong $M$. Breast cancer sentinel lymph node mapping using near-infrared guided indocyanine green in comparison with blue dye. Tumour Biol. 2014;35(4):3073-8.

32 Thill M, Kurylcio A, Welter R, van Haasteren V , Grosse B, Berclaz G, et al. The CentralEuropean SentiMag study: sentinel lymph node biopsy with superparamagnetic iron oxide (SPIO) vs. radioisotope. Breast. 2014;23(2):175-9.
33 Madrona A , Richart J , Carrillo J, Parga G , Cecilia $J$, Cunchillos $F$, et al. Superparamagnetic iron oxide as a tracer for sentinel node biopsy in breast cancer: a comparative non-inferiority study. Eur J Surg Oncol . 2015;41(8):991-7.

34 Rubio I, Botero S , Esgueva A, Rodriguez R, Cortadellas $\mathrm{T}$, Cordoba $\mathrm{O}$, et al. The superparamagnetic iron oxide is equivalent to the Tc99 radiotracer method for identifying the sentinel lymph node in breast cancer. Eur J Surg Oncol. 2015;41(1):46-51.

35 Tafra L, Lannin D, Swanson M, Van Eyk J , Verbanac K, Chua A, et al. Multicenter trial of sentinel node biopsy for breast cancer using both technetium sulfur colloid and isosulfan blue dye. Ann Surg . 2001;233(1):51-59. 